\title{
EVALUATION OF MENTAL WELL-BEING AND GENERAL HEALTH POINTS OF ATHLETES
}

\author{
Spor Yapan Bireylerin Genel Sağlık Durumları \\ ile Mental İyi Oluşlarının Değerlendirilmesi
}

Gönderim Tarihi: 18.10.2017

Kabul Tarihi: 08.12.2017

Neslihan LÖK"

\begin{abstract}
The aim of this study was to evaluate the general health status and mental well being of the sports individuals. Research type is descriptive relational. The study's universe was included in the sampling of all individuals who had included a programmed athlete and who agreed to participate in the study using random sampling method. 67 athletes who agreed to participate in the survey have formed a sample. Sociodemographic information form, General Health Questionnaire and Mental Well-Being Scale were used to collect data. The data were collected in the classroom environment after the course in which the athletes were collectively trained. Participants' mean scores from the general health questionnaire were 2,47 $\pm 0,91$ and mean scores from the mental wellbeing scale were $51,31 \pm$ 8,42 . When the relationship between participants' general health questionnaire and mental well-being score averages were examined, it was found that there was a strong correlation in the positive direction $(r=-0,742, p=0,08)$. In line with the results of this research; men, secondary school graduates, and those who are engaged in sports for 1-4 years have taken place in the risk group in terms of general health and mental well being. Individuals' overall health point averages were also found to increase mental well-being. When the athletes from the mental side feel good they are generally well aware of their health.
\end{abstract}

Keywords: Mental Well-Being, General Health, Sports.

ÖZ: Spor yapan bireylerin genel sağlık durumları ile mental iyi oluşlarının değerlendirilmesi amacıyla yapılmıştır. Araştırma tanımlayıcı ilişkisel türdedir. Araştırmanın evrenini bir programa dahil edilen sporcular oluşturmuş ve gelişigüzel örnekleme yöntemi kullanılarak araştırmaya katılmayı kabul eden tüm bireyler örnekleme dahil edilmiştir. Araştırmayı katılmayı kabul eden 67 sporcu örneklemi oluşturmuştur. Verilerin toplanmasında

*Yrd. Doç. Dr., Selçuk Üniversitesi/Sağlık Bilimleri Fakültesi/Hemşirelik Bölümü/Psikiyatri Hemşireliği Anabilim Dalı, neslihanlok@selcuk.edu.tr, ORCID ID: orcid.org/0000-0003-1568-9659 
sosyodemografik bilgi formu, Genel Sağlık Anketi ve Mental İyi Oluş Ölçeği kullanılmıştır. Veriler sporcuların toplu olarak eğitim aldıkları kurs sonrası sınıf ortamında toplanmıştır.

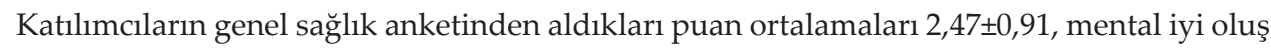

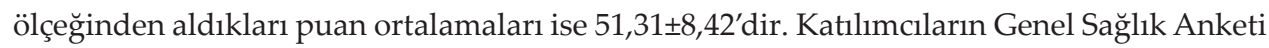
ve Mental İyi Oluş Ölçeği puan ortalamaları arasındaki ilişki incelendiğinde, pozitif yönde güçlü bir ilişki olduğu görülmüştür ( $r=-0,742, p=0,08)$. Bu araştırmanın sonuçları doğrultusunda; erkekler, ortaöğretim mezunları ve 1-4 yıl arası süredir spor yapanlar genel sağlık ve mental iyi oluş açısından risk grubunda yer almıştır. Bireylerin genel sağlık puan ortalamaları artıkça mental iyi oluşlarının da arttığı görülmüştür. Mental yönden sporcular kendilerini iyi hissettiklerinde genel olarak sağlı̆̆ını da iyi algılayacakları sonucuna varılmıştır.

Anahtar Kelimeler: Mental İyi Oluş, Genel Sağlık, Spor.

\section{INTRODUCTION}

According to the World Health Organization, health is considered good form in all physical, mental and social dimensions and has not changed since 1958 (World Health Organization, 2003). A sport contributes to the physical, emotional and social development of people and has positive effects on healthy life (Çebi et al., 1986; Şahin et al. 2017a). At the same time, the importance of athletes has been revealed with the evaluation of leisure time, self-confidence, socialization and solidarity, as well as exploring the role of physical and mental health in the development (Sahin et al., 2012; Lök and Bademli, 2016; Lök and Lök, 2016).

Physical inactivity increases in the prevalence of obesity and physical inactivity. Inadequate physical activity is associated with diseases such as coronary heart disease, diabetes, and osteoporosis. Lifelong regular physical activity is important for physical and mental health (Eime et al., 2015; Şahin et al., 2017b; Lök and Lök, 2016; Lök et al., 2017, Lok et al. 2017). Sports are one of the physical activities that can contribute to health (Khan et al., 2012). In the literature review by Penedo and Dahn, (2005), most studies in the literature suggest that regular sport has a positive impact on physical health and increases quality of life.

In recent years, there has been an increase in studies on the development of sports mental health and factors affecting mental health. Increasing self-esteem (Ekinci et al., 2014), increasing assertiveness (Bademli, 2017; Gacar and Yanliç, 2012; Korkmaz, 2007; Şahin et al.,2017c), increasing participation in sports activities (Öztürk et al., 2011) Inan, 2010) has been shown to reduce the level of anxiety (Petruzzello 1991) and to be protective against depression (Babiss and Gangwisch, 2009; Sahin et al., 2017a; Sahin et al., 2017b). Stanton et al., (2014) 
reported that there was a large number of studies indicating that participation in long-term physical activity prevented depression. Sport is an important variable in terms of physical and mental health. For this reason, it is important to evaluate the general health status and the mental health status of the active sportsmen. In this study which is planned for this purpose, the general health status and mental well being of the active sportsmen were evaluated.

\section{MATERIAL AND METHODS}

Research is planned in a descriptive relational type. The study's universe was included in a sample of all the individuals who participated in the study, including a programmer who included a programmer and who did not go to the sample selection method. 67 athletes who agreed to participate in the survey have formed a sample. Sociodemographic information form, General Health Questionnaire and Mental Well-Being Scale were used to collect data. The data were collected in a post-training classroom environment where athletes were collectively trained.

General Health Questionnaire-12: Validity and reliability study for our country The form made by Kılıç (1996) is used to find psychiatric cases in community screenings. General Health Questionnaire was developed by David Goldberg (1970) to identify acute mental illnesses that are common in the community. It is stated that it can be used safely in the detection of non-psychotic depression and anxiety symptoms, it is not recommended to use it in the detection of psychotic and manic patients and chronic psychiatric patients. The scale, which aims to determine whether the patients are completing themselves and whether they are generally mental disorders, is used to screen for mental illnesses that have occurred in the last weeks in patients who have applied to a health institution with a health problem. There are 12,28,30 and 60 questions. Each question is queried and queried in the last few weeks ("never, ever, often, often," ever), these four columns are coded as 0,1,2,3 by the responder, or responses read aloud by the practitioner It is coded. Individuals who score above " 5 " are identified as mentally ill (anxiety and depression). Those who score less than 2 points on the scale are low, those who score 2-3 points are medium, and those who score 4 or more are grouped as high scores. It is accepted as a cut-off point of 2 points in case determination by GSA-12. It is considered that general health is better as the total score from the scale decreases. The method called GHQ type scoring used in the evaluation of General Health Questionnaire was used in the scores. Accordingly, the first two columns are scored 0 , and the last two columns are scored 1 (Kılıç, 1996). In our study, cronbach alpha value was calculated as 0.83 . 
The Warwick-Edinburgh Mental Well-Being Scale: Tennant et al. (2007) were developed to measure the mental well-being of individuals living in the UK. The Mental Well-Being is composed of 14 items and deals with the positive mental health of individuals, including psychological well-being and subjective well-being. Scale is in Likert type of 5 and it is taken at least 14 and maximum 70 points from the scale. Your score is scored $(1=$ not at all, $2=$ not agreeing, $3=$ somewhat agreeing, $4=$ agreeing, $5=$ fully agreeing). All the things you measure are positive. It is accepted that the score taken from the scale increases in the case of residual goodness. The reliability of your scale was studied with 16 and older individuals. Cronbach's Alfa internal consistency reliability coefficient was 0.92, which was adapted to Turkish by Chalcedan (2015), validity and reliability scale (Chalced, 2015). In our study, cronbach alpha value was calculated as 0.79 .

\section{Collection of data}

The data of this study were collected from active sporting individuals. It was started after the ethics approval for the search. At the time of data collection, the sportsmen who accepted to participate in the survey were informed by the researchers that the form was signed and the form was signed by those who agreed to participate in the investigation by providing the meaning of the purpose and extent of the research. Before the forms to be used in the research were given, necessary explanations were made orally and care was taken to create a silent environment with little stimulation during application.

\section{Evaluation of Data}

After the data were collected, the option that each individual indicated for each item on the scales was entered into the SPSS program by the researchers and the total scores of the individuals from the scales were calculated. The Kolmogorov Smirnov test, in which the data fit the normal distribution, was tested and the data showed a normal distribution. In the evaluation of demographic data of the study, number and percentage distributions, $t$ test to assess the relationship between socio demographic characteristics and Stress Relief Scale, and correlation analysis to evaluate the relationship between two scales. The results were assessed at $95 \%$ confidence interval and $\mathrm{p}<0.05$ significance level.

\section{Limitations of the Study}

This research; Taekwondo is limited to those who come to the course program for training, who are open to communication and who agree to participate in the survey. 


\section{RESULTS}

Table 1. Participants' distribution of points averages from scales

\begin{tabular}{lcc}
\hline Variables & Min-Max & Mean \pm SD \\
\hline GHQ & $38-64$ & $2,47 \pm 0,91$ \\
\hline MWB & $1-6$ & $51,31 \pm 8,42$ \\
\hline
\end{tabular}

When the socio-demographic characteristics of the participants and the general health questionnaire points were examined, it was found that women $(2,32$ $\pm 0,81)$, bachelors $(1,45 \pm 0,88)$ and those who were engaged in sports for 5 years or longer $(1,40 \pm 0,42)$ were found to be better and the difference was statistically significant $(p<0,05)$. It is statistically insignificant $(p>0,05)$ that the difference between the general health point averages $(2,41 \pm 1,00)$ of university graduates is better than the secondary school graduates. When the participants' socio-demographic characteristics and mental well-being averages were examined, it was found that women $(52,37 \pm 8,28)$, bachelors $(54,60 \pm 7,92) 87)$ were found to be better and the difference was statistically significant $(p<0,05)$. The difference between the mean scores of mental well-being of university graduates (52.05 \pm 8.93$)$ is better than that of secondary education graduates is statistically insignificant ( $\mathrm{p}>0.05$ ) (Table 2).

Table 2. Distribution of Participants' Socio-Demographic Characteristics, General Health Questionnaire and Mental Well-being Scale Score Averages

\begin{tabular}{lll}
\hline & GHQ & MWB \\
\hline Gender & $2,32 \pm 0,81$ & \\
\hline Female & $2,63 \pm 0,99$ & $52,37 \pm 8,28$ \\
\hline Male & $\mathrm{t}=1.095$ & $50,22 \pm 8,54$ \\
\hline $\mathrm{t}^{\prime}$ & $\mathrm{p}=0.01^{*}$ & $\mathrm{t}=1,478$ \\
$\mathrm{p}$ & & $\mathrm{p}=0.02^{*}$ \\
\hline Mariatal Status & $3,49 \pm 0,93$ & \\
\hline Married & $1,45 \pm 0,88$ & $50,07 \pm 8,34$ \\
\hline Not married & $\mathrm{t}=0,168$ & $54,60 \pm 7,92$ \\
\hline $\mathrm{t}^{\prime}$ & $\mathrm{p}=0,01$ & $\mathrm{t}=-2,094$ \\
$\mathrm{p}$ & & $\mathrm{p}=0,02^{*}$ \\
\hline Education & $2,52 \pm 0,98$ & \\
\hline Secondary & $2,41 \pm 1,00$ & $50,00 \pm 6,24$ \\
\hline University & $\mathrm{t}=-0,391$ & $52,05 \pm 8,93$ \\
\hline $\mathrm{t}^{\prime}$ & $\mathrm{p}=0,12$ & $\mathrm{t}=0,903$ \\
$\mathrm{p}$ & & $\mathrm{p}=0,74$ \\
\hline Duration of sports & $3,48 \pm 0,93$ & \\
\hline $1-4$ years & $1,40 \pm 0,42$ & $47,27 \pm 8,46$ \\
\hline 5 and over & $\mathrm{t}=-0,200$ & $\mathrm{t}=0,132$ \\
\hline $\mathrm{t}^{\prime}$ & $\mathrm{p}=0,01^{*}$ & $\mathrm{p}=0,04^{*}$ \\
\hline $\mathrm{p}$ &
\end{tabular}

$p<0,05$ 
When the relationship between participants' general health questionnaire and mental well-being score averages were examined, it was found that there was a strong correlation in the positive direction $(\mathrm{r}=0,742, \mathrm{p}=0,08)$. Individuals' overall health point averages were also found to have increased residual mental well-being (Table 3).

Table 3. Relationship between participants' general health questionnaire and mental well-being score averages

\begin{tabular}{lll}
\hline & MWB & GHQ \\
\hline MWB & 1,00 & \\
\hline \multirow{2}{*}{ GHQ } & $\mathrm{r}=0,742$ & \\
& $\mathrm{p}=0,08^{*}$ & 1,00 \\
\hline
\end{tabular}

\section{DISCUSSION}

The present findings suggest the effects of active sport on general health and mental health for non-clinical populations. Findings from the study show that the general health status of those who are engaged in sports for 5 years or longer is significantly better than those who play sports for 1-4 years. This finding can be explained as a positive effect of regular and long-term sports on general health and mental health. Regular and effective exercise programs are important and one of the most economical ways to protect against disease and supportive care. Positive effects of regular physical exercise on health are revealed during studies. Penedo and Dahn (2005) state that exercise, physical activity and physical-activity interventions have beneficial effects across physical and mental-health outcomes.

Regular sport may have similar positive effects for clinical and non-clinical populations. studies have shown that regular exercise is positively affecting individuals with mental health problems such as depression and anxiety (Johnson, 1997; Ucaktan et al., 2004; Karacabey, 2005; Bademli and Lök, 2017; Bademli et al., 2017). In a study conducted by Callaghan (2004) found that exercise improves mental health and well-being, reduces depression and anxiety and enhances cognitive functioning. Regular physical exercise is an outstanding opportunity for patients who have a mental and physical health problems (Knapen et al., 2015). In the meta-analysis study conducted by Rebar et al., (2015), similarly, it provides evidence that physical activity reduces depression by a medium amount and anxiety by a small amount in non-clinical populations. Findings from this study show that active men are at risk for mental well-being compared to women who are active sportsmen. In the study conducted by Hosseini and Besharat, (2010), there was no difference between male and female mental well-being. 


\section{CONCLUSION}

In another study, in contrast to our work, Female athletes become more anxious and tense, and more emotion-focused coping strategies, than male athletes. This can be explained by cultural differences. Possible differences that can be produced in sports such as psychological endurance, life satisfaction, happiness, other positive mental health variables such as life purpose can also be tested. 


\section{REFERENCES}

Babiss, L. A. and Gangwisch, J. E. (2009). Sports participation as a protective factor against depression and suicidal ideation in adolescents as mediated by self-esteem and social support. Journal of Developmental \& Behavioral Pediatrics, 30(5), 376-384.

Bademli K. Anxiety and Depression in Caregivers of Chronic Mental Illness, Journal of Depression and Anxiety, 2017;6:1.

Bademli, K. and Lök, N. (2017). Help Seeking Behaviors in Chronic Mental Diseases. Psikiyatride Guncel Yaklasimlar-Current Approaches in Psychiatry, 9(2), 136-146.

Bademli, K., Lök, N., and Kılıc, A. K. (2017). Relationship Between Caregiving Burden and Anger Level in Primary Caregivers of Individuals With Chronic Mental Illness. Archives of psychiatric nursing, 31(3), 263-268..

Callaghan, P. (2004). Exercise: a neglected intervention in mental health care?. Journal of psychiatric and mental health nursing, 11(4), 476-483.

Çebi, M., Yamak, B., and Öztürk, M. (2016). 11-14 Yaş Çağındaki Çocukların Spor Yapma Alışkanlığının Duygu Kontrolü Üzerine Etkilerinin İncelenmesi. Amasya Üniversitesi Ĕ̆itim Fakültesi Dergisi, 5(2), 468-482.

Eime, R. M., Sawyer, N., Harvey, J. T., Casey, M. M., Westerbeek, H., and Payne, W. R. (2015). Integrating public health and sport management: sport participation trends 2001-2010. Sport management review, 18(2), 207-217.

Ekinci, N. E., Özdilek, Ç., Deryahanoğlu, G., and Üstün, Ü. D. (2014). Spor yapan lise öğrencilerinin öz güven düzeylerinin incelenmesi. Sportif Bakış: Spor ve Eğitim Bilimleri Dergisi, 1(1), 36-42.

Gacar, A., and Yanlıç, N. (2012). 13-17 Yaş Ergen Hentbolcuların Benlik Saygısı Düzeylerinin Bazı Değişkenler Açısından İncelenmesi. Spor Ve Performans Araştırmaları Dergisi, 3(2).

Hosseini, S. A., and Besharat, M. A. (2010). Relation of resilience whit sport achievement and mental health in a sample of athletes. Procedia-Social and Behavioral Sciences, 5, 633-638.

Inan, T. (2010). Relationshıp Between Physıcal Actıvıty Level And Assertıveness Score Of Students Studying At The School Of Physical Education And Sports. Sport Sciences, 5(3), 218-226.

Johnson, U. (1997). Coping strategies among long-term injured competitive athletes: a study of 81 men and women in team and individual sports. Scand J Med Sci Sports. 7(6):367-72. 
Karacabey, K. (2005). Effect of regular exercise on health and disease. Neuro Endocrinol Lett, 26(5).

Khan, K. M., Thompson, A. M., Blair, S. N., Sallis, J. F., Powell, K. E., Bull, F. C., and Bauman, A. E. (2012). Sport and exercise as contributors to the health of nations. The Lancet, 380(9836), 59-64.

Knapen, J., Vancampfort, D., Moriën, Y., and Marchal, Y. (2015). Exercise therapy improves both mental and physical health in patients with major depression. Disability and rehabilitation, 37(16), 1490-1495.

Lok, N., Lok, S. and Canbaz, M. (2017). The effect of physical activity on depressive symptoms and quality of life among elderly nursing home residents: Randomized controlled trial. Archives of gerontology and geriatrics, 70, 92-98.

Lök, N. and Bademli, K. (2016). Effectiveness of Music Therapy in Alzheimer Patients: Systematic Review. Psikiyatride Guncel Yaklasimlar-Current Approaches in Psychiatry, 8(3), 266-274.

Lök, N., \& Bademli, K. (2017). Pilot testing of the "First You Should Get Stronger" program among caregivers of older adults with dementia. Archives of gerontology and geriatrics, 68, 84-89.

Lök, S. and Lök, N. (2015). Physical Activity and Exercise in Dementia. Psikiyatride Guncel Yaklasimlar-Current Approaches in Psychiatry, 7(3), 289-294.

Lök, S. and Lök, N. (2016). Kronik Psikiyatri Hastalarına Uygulanan Fiziksel Egsersiz Programlarının Etkinliği: Sistematik Derleme. Current Approaches in Psychiatry/Psikiyatride Guncel Yaklasimlar, 8(4).

Ocaktan, M. E., Özdemir, O., and Akdur, R. (2004). Birinci Basamakta Ruh Sağlığ1 Hizmetleri. Kriz dergisi, 12(2), 63-73.

Öztürk, Ö. T., Soytürk, M., Ada, E. N. D., and Çamlıyer, H. (2011). Üniversite Takımlarında Sporcu Olan Öğrencilerle Spor Yapmayan Öğrencilerin İletişim Becerisi Düzeylerinin Karşılaştırılması. Spor Bilimleri Dergisi, 22(2), 43-53.

Penedo, F. J., and Dahn, J. R. (2005). Exercise and well-being: a review of mental and physical health benefits associated with physical activity. Current opinion in psychiatry, 18(2), 189-193.

Penedo, F. J., and Dahn, J. R. (2005). Exercise and well-being: a review of mental and physical health benefits associated with physical activity. Current opinion in psychiatry, 18(2), 189-193. 
Petruzzello, S. J., Landers, D. M., Hatfield, B. D., Kubitz, K. A., and Salazar, W. (1991). A meta-analysis on the anxiety-reducing effects of acute and chronic exercise. Sports medicine, 11(3), 143-182.

Rebar, A. L., Stanton, R., Geard, D., Short, C., Duncan, M. J., and Vandelanotte, C. (2015). A meta-meta-analysis of the effect of physical activity on depression and anxiety in non-clinical adult populations. Health psychology review, 9(3), 366-378.

Sahin M, Sagırkaya A, Lok N, Bademli K, Büyükergin A, Lok S. Effects Of Sports In Adult Daughter Stressing Styles. Science, Movement and Health, Vol. XVII, ISSUE 2 Supplement, 2017 September 2017, 17 (2, Supplement): 475-479.

Sahin M, Sagırkaya A, Lok N, Bademli K, Tav KH, Lok S. Evaluation Of Relationship Between Resilience And Physical Activity Levels Of National Sports. Science, Movement and Health, Vol. XVII, ISSUE 2 Supplement, 2017 September 2017, 17 (2, Supplement): 470-474.

Stanton, R., Happell, B., and Reaburn, P. (2014). The mental health benefits of regular physical activity, and its role in preventing future depressive illness. Nursing: Research and Reviews, 4, 45-53.

Şahin, M., Yetim, A. A., and Çelik, A. (2012). Psikolojik sağlamlığın gelişiminde koruyucu bir faktör olarak spor ve fiziksel aktivite. The Journal of Academic Social Science Studies, 5(8), 373-380.

World Health Organization (2003). WHO definition of health, http://www. who.int/about/definition/en/print.html. 